\title{
The Students' Perception on Self-Image, Tourism Career, and Job Choice
}

\author{
Heri Puspito Diyah Setiyorini \\ Tourism Marketing Management Study Program \\ Universitas Pendidikan Indonesia \\ Bandung, Indonesia \\ hp_diyah@upi.edu
}

\author{
Elly Malihah \\ Sociology Education Department \\ Universitas Pendidikan Indonesia \\ Bandung, Indonesia \\ fivally@yahoo.com \\ Rini Andari \\ Tourism Marketing Management Study Program \\ Universitas Pendidikan Indonesia \\ Bandung, Indonesia \\ riniandari@upi.edu
}

\begin{abstract}
The purpose of this study is to understand the perception of tourism and hospitality students self image, the tourism and hospitality career, and the job choice. The initial perception about career image could drive the student's eagerness to finish the study and prepare their career path in this business. The research was a descriptive and explanatory research. The data was compiled through an on-line survey to the students in several universities in Bandung, Indonesia. There were 351 valid responses that were analyzed by multiple regression methods. Descriptive analysis showed that the student's self-image was high students had a high perception on their character of willingness to help others, but the character of emotional control was perceived to be lesser. Regarding to the tourism career image, students perceived the high interest of the good tourism and hospitality people appearance, while their perception of the community acceptance of working in the tourism and hospitality industry was perceived to be lesser. The last thing was that students perceived a great interest in being an entrepreneur in tourism and hospitality business. However, they perceived a lower interest at being a teacher at the secondary level. The multiple regression analysis showed that the self-image and tourism career image could predict the job choice of tourism.
\end{abstract}

Keywords- tourism and hospitality education, characters, career perception and choice

\section{INTRODUCTION}

The increasing number of tourism business has generated job or occupation for many people. The job itself has also attracted students to develop the career in the industry. Thus, the students pursue the tourism and hospitality education to be prepared of working in the industry.

There are some terminologies in defining the tourism industry. The tourism itself refers to some occupations that deal within the attractions. The examples of the jobs are the manager of theme parks, recreation park, destination management company, or tourism office in a country or region. The jobs that deal with hotels, restaurants, or catering services are referred to the hospitality industry. While the jobs that refers to the tour operation, travel agency, or meeting or convention services are referred to the travel industry. There are also tourism-related occupations, such as a teacher at the secondary-level vocational school or lecturer. To simplify the terminology, this article will use tourism career to resemble the hospitality travel, and other related tourism careers altogether. In Indonesia, the terminology of tourism is called "pariwisata" and all the terminologies of tourism are represented in that word.

There are many factors that make students to choose a career after they have graduated from school, such as the student's motivation, references group or the image of the industry. This research will focus on the perception of selfcharacteristics and the career of tourism as the antecedents in choosing the tourism career.

\section{LITERATURE}

\section{A. Tourism Education}

Tourism education has played as an important sector in developing the industry to leverage the country's tourism competitiveness. As an institution that prepares human resources to develop the tourism industry, tourism education emphasizes its education on the ability to reach the human resources competent and employability. The number of institutions that held the tourism education has been increased rapidly (Petorva \& Dorota, 2006). In tourism education Airey and Johnson (1999) as cited in Petrova and Ujma (2006) stated that the key elements of the tourism materials that are given to the students consist of vocational, career, and industry. Thus, 
it could help the students to be more prepared in working within the industry.

\section{B. Self-Image}

Self-image is important in developing career because according to Uygur and Killie (2009), that the job involvement is determined by the understanding of the job importance that has a strong relationship to the self-image and self-concept. The self-image is the way an individual perceived the impression of the characteristics and personality traits. The tourism human resources self-image consists of their willingness to help people, meeting with the new people, the social skills, hard-working attitude, creativity, obedience, courtesy, communication skills, personal hygiene, and spiritual life.

\section{Tourism Career Image}

Tourism career image, in some research has been characterized as the job of working conditions, ignoble career prospects, low pay, seasonality, and because there is excessive service activity, it bears the poor image (Jensen, 2000). Even empirically, in some part of Indonesian region, the community still perceive tourism as an inferior business. However, tourism provides a diverse range of job variety (Burns, 1993). Hence, the entry level of the people to the industry is easier (Szivas, Riley, and Airey, 2003). Thus, this research generates indicators for tourism career image on the attractiveness, the salary, the family perception, the community acceptance, the job environment, the variety of the job, and the assurance for the future.

\section{Tourism Job Choice}

Understanding the relationship between education and job has been studied by many scholars (Ladkin 1999; Marchante, Ortega, Pagan, 2007; Morrison \& Johnston, 2003; Johnston 2000, Jackson 2015, etc.). Jackson (2015) and King (2004) noted that pursuing the job or career includes some activities such as understanding the labour market, developing professional networking, having self-awareness and ability to search the job, as well as establishing the career goals. Jackson (2015) furthermore, stated some determinants that influence the job or career choice, such as: a) gender (Gati, AsulinParetz, \& Fisher, 2012), b) socio-economic status (Zellweger, Siedger, and Halter, 2011), c) personality (Rees, Bruuch, \& Hasee, 2004), d) self-efficacy (Jain \& Jain, 2013), e) perceived employability (Mc Ilveen, Burton, Beccaria, 2013), f) vocational interests (Roberstson, Smeets, Lubinski, \& Benbow, 2010), and g) broader factors, including labour market trends and economic certainty (Agarwala, 2008).

Walsh, Chang, and Tse (2015) stated that many researchers and educators were interested in understanding the student's career intention, especially the degree to which they wish to develop careers in the tourism and hospitality industry. However, in their study, they also discovered that the trend of the students that would not enter their career in the tourism and hospitality career has been increased. The reason is that because they perceived values of the industry characteristics are difficult, for example, the salary, the work-life balance, and the challenge (Kelly-Patterson and George, 2001; O'Leary and Deegan 2005; Richardson, 2009). Moreover, the demand of having a specific individual level of personality traits also determine the student's preferences in deciding the tourism job or career (Chuang and Dellman-Jenkins, 2010; Teng 2008). Hence, the research paradigm is as stated in figure 1 , as follows:

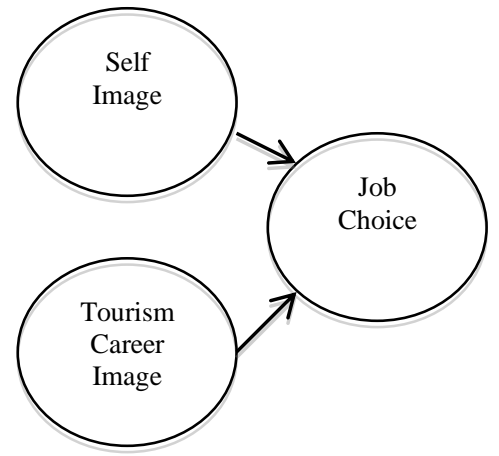

Figure 1: The research paradigm

\section{RESEARCH METHOD}

The research method used in this research is descriptive and explanatory research. The variables of this research are tourism characteristics and the perception of tourism career as the independent variable and tourism career choice as the dependent variable.

The data were collected by on-line survey to 400 students. However, the valid response that was used in the analysis was from 351 students. The survey was conducted in tourism schools and universities in Bandung, Indonesia. The data then analyzed by multiple regression analysis to understand whether the independent variables were having influences to the dependent ones.

The hypothesis of this research was as follows:

$\mathrm{H}_{0}=$ The students' self-image and their perception on the career in tourism have no significant influence to the career choice.

$\mathrm{H}_{\mathrm{a}}=$ The students' self-image and their perception on the career in tourism have a significant influence to $t$ he career choice.

\section{RESULT AND DISCUSSION}

The survey was conducted in several tourism schools and universities in Bandung, Indonesia during September November 2015 while they were having the first term of the study. There are two terms of study in Indonesia, the FirstTerm Semester (Odd Semester) and Second-Term Semester (Even Semester). So, there were students at the $1^{\text {st }}, 3^{\text {rd }}, 5^{\text {th }}$, and $7^{\text {th }}$ Semester's students during the First Term Semester.

There were $62,86 \%$ female students and $37,32 \%$ male students, and mostly at the age of 19 years old (26,78\%), 18 years old $(23,36 \%)$, and 20 years old $(23,08 \%)$. The location of the universities/schools in this research was in West Java, so the majority of the students were Sundanese $(58,40 \%)$, there 
were also Javanese students (19,37\%), and other students from Jakarta, Batak, Padang, Sulawesi, Kalimantan, Nusa Tenggara, and Kalimantan $(9,69 \%)$. The research was conducted for Students at Master degree, Bachelor degree and Diploma degree students, their previous education was Senior Highschool/SMA (76,64\%), Tourism Vocational Secondary Level/SMK Pariwisata (14,25\%), Diploma IV or Bachelor Degree $(2,85 \%)$, Diploma III $(1,99 \%)$, and other Vocational School at Secondary Level $(0,85 \%)$ such as from technical, marketing, business management, accounting, broadcasting, multimedia, telecommunication as their major.

The students were taking Bachelor Degree/S1 (61,03\%), Diploma IV (18,91\%), Diploma III (17,77\%), and Master Degree $(2,29 \%)$. This data shows that the number of academic degree in tourism and hospitality is increasing. There were three universities in Bandung that held the academic degree of education such as Universitas Pendidikan Indonesia (UPI), Sekolah Tinggi Pariwisata Bandung (STPB), and Sekolah Tinggi Ilmu Ekonomi Pariwisata (STIEPAR). STPB also held diploma/vocational degree for tourism and hospitality, other universities such as Bandung Polytechnic and Telkom University also held the Diploma Degree. The respondents in this research were from UPI $(46,44 \%)$, STPB $(45,87 \%)$, Bandung Polytechnic $(7,41 \%)$, and STIEPAR $(0,28 \%)$. Their major were at Hospitality $(25,07 \%)$, Tourism $(14,25 \%)$, Travel $(21,65 \%)$, and Mixed (39,03\%). Mixed major means the schools offer tourism science that has not specified in hospitality, tourism, or travel industry.

Most of the respondents were at the third semester or second year $(30,46 \%)$ and first semester or first year $(29,60 \%)$. There were $19,54 \%$ from the $5^{\text {th }}$ semester, $10,63 \%$ from the $7^{\text {th }}$ semester, and $8,05 \%$ that exceed the $8^{\text {th }}$ semester or more than 4 year at the campus. There were $59,03 \%$ who has been experienced in working at the tourism industry. Thus, most of the respondents has known about the tourism job situation.

The result of the students perception on their self characteristics, tourism career, and the career choice are summarized as follow:

TABLE I. THE SCORE OF VARIABLES AND INDICATORS

\begin{tabular}{|l|l|}
\hline \multicolumn{1}{|c|}{ Variabel and Indicators } & Score \\
\hline Self-Image & \\
\hline Willingness to Help People * & 1,465 \\
\hline Preferences in having acquaintance to new people & 1,440 \\
\hline Discipline Attitude & 1,334 \\
\hline Controlling Emotion/Temper ** & 1,301 \\
\hline Social Skils & 1,361 \\
\hline Pleasant Personality & 1,450 \\
\hline Hardworking Attitude & 1,399 \\
\hline Attention to Details & 1,444 \\
\hline Creativity & 1,366 \\
\hline Obeying Regulations & 1,381 \\
\hline Spiritual Life & 1,311 \\
\hline Courtesy Attitude & 1,454 \\
\hline Communication Skills & 1,349 \\
\hline Personal Hygiene & 1,431 \\
\hline Perception of Tourism Career & \\
\hline Tourism and Hospitality Attractiveness & 1,522 \\
\hline
\end{tabular}

\begin{tabular}{|l|l|}
\hline \multicolumn{1}{|c|}{ Variabel and Indicators } & Score \\
\hline $\begin{array}{l}\text { Preferences on the appearance of the people who works at } \\
\text { the Tourism and Hospitality Industry* }\end{array}$ & 1,547 \\
\hline $\begin{array}{l}\text { Preferences of the work environment of Tourism and } \\
\text { Hospitality Industry }\end{array}$ & 1,527 \\
\hline $\begin{array}{l}\text { There are many job variation in Tourism and Hospitality } \\
\text { Business, so I think working there will not be boring }\end{array}$ & 1,503 \\
\hline Tourism and hospitality industry offers a high salary & 1,424 \\
\hline $\begin{array}{l}\text { My surrounding community perceive that Working in } \\
\text { Tourism and Hospitality Industry has Positive Value** }\end{array}$ & 1,357 \\
\hline $\begin{array}{l}\text { My family support my choice in pursuing Tourism and } \\
\text { Hospitality Career }\end{array}$ & 1,532 \\
\hline $\begin{array}{l}\text { The career in the Tourism and Hospitality Business can } \\
\text { secure my future }\end{array}$ & 1,397 \\
\hline Job Choice & 1,484 \\
\hline $\begin{array}{l}\text { I want to be an entrepreneur in tourism and hospitality } \\
\text { business* }\end{array}$ & 1,293 \\
\hline I want to work at the hotel & 1,237 \\
\hline I want to work at the restaurant & 1,315 \\
\hline I want to work at tour operator/travel agency & 1,329 \\
\hline I want to work at the recreation park & 1,470 \\
\hline I want to work at the government tourism office & 1,401 \\
\hline I want to work at the tourism and hospitality consultant \\
\hline $\begin{array}{l}\text { I want to work at the Professional Conference } \\
\text { Organiser/Event Organiser }\end{array}$ & 1,149 \\
\hline I want to be a tourism and hospitality lecturer \\
\hline $\begin{array}{l}\text { I want to be a teacher at tourism and hospitality vocational } \\
\text { school (secondary level) ** }\end{array}$ & 1,317 \\
\hline I want to be a tourism hospitality researcher & \\
\hline & \\
\hline
\end{tabular}

The scores are calculated by multiplying the frequency of the responses with the Likert scale used in the questionnaires. This research used 5 Likert scale as the representative of respondents' response. The result of the self-image, it is found that the students perceived a strong image on the willingness to help others, but they perceived low in controlling the temper. Regarding to the perception of tourism career, the students perceived that the appearance of the tourism career was strong and that became the strong image and preferences toward the career. However, their perception of the community image regarding to the tourism activity was considered to be lower. The career choice that mostly preferred was becoming an entrepreneur in tourism and hospitality business. However, working as a tourism teacher at secondary vocational school were consider to be lower or less attractive than other profession.

The result of multiple regression analysis show that there were a strong influence on the student's self image and their perception on the tourism career towards the job choice. The result is as follow:

TABLE II. REGRESSION STATISTICS RESUlTS

\begin{tabular}{lr} 
Regression Statistics & \\
\hline$R$ & 0.98406 \\
$R$-square & 0.96836 \\
Adjusted R-square & 0.96827 \\
$S$ & 6.74391 \\
$N$ & 351
\end{tabular}


The $\mathrm{R}^{2}$ is 0,96827 that means the self-image and the tourism career image has influenced the job choice significantly, as for $96,83 \%$.

The multiple regression equation of the variables observed in this research are as follow:

$$
\begin{aligned}
\text { Job Choice }(Y)= & 0+0.43055 * \text { Self Image }(X 1)+0.42182 * \\
& \text { Tourism Career Image }(X 2)
\end{aligned}
$$

The intercept was 0 , the coefficient of the self image is 0,43055 , while the coefficient of the tourism career image was 0,42183 . There is a slight difference between the self image and career image but both of them has significant value in influencing the job choice. Thus, the null hypotheses is rejected. This explanation is as follows:

\begin{tabular}{|c|c|c|c|c|c|c|c|}
\hline & $\begin{array}{l}\text { Coeffi } \\
\text {-cient }\end{array}$ & $\begin{array}{l}\text { Standard } \\
\text { Error }\end{array}$ & $L C L$ & $U C L$ & $t$ Stat & $p$-level & $\mathrm{HO}(5 \%)$ \\
\hline Intercept & 0 & & & & & & \\
\hline $\begin{array}{l}\text { Self } \\
\text { Image } \\
(\text { X1) }\end{array}$ & 0.430 & 0.052 & 0.328 & 0.532 & 8.275 & 0. & rejected \\
\hline $\begin{array}{l}\text { Tourism } \\
\text { Career } \\
\text { Image } \\
\text { (X2) }\end{array}$ & 0.421 & 0.085 & 0.253 & 0.589 & 4.938 & $\begin{array}{r}1.2225 \\
4 \mathrm{E}-6\end{array}$ & rejected \\
\hline
\end{tabular}

TABLE III. ANOVA RESULTS

This research was strengthen the ides of Uygur and Killie (2009) stated before that understanding the job involvement is determined by the understanding of the job importance that has a strong relationship to the self-image and self-concept. It also can be interpreted that the self-image could lead to the job of what students would choose in the future. Hence, if they had a tourism related image in their self-perception, they would likely to choose career in this sectors.

Walsh, Chang, and Tse (2015) stated that many researchers and educators had come up with the conclusion that he trend of the students that would not enter their career in the tourism and hospitality career has been increased. It could mean that the industry attractiveness was also increase. Thus, the phenomenon was in line with this research result findings that had shown the relationship between the tourism career and the job choice.

\section{CONCLUSION}

The result shows that there are a strong influence between the self image and career image to the students' job choice. This result implies that, the affirmation on letting the students understand the job environment as well as acquiring good personality or self image will lead their career path in tourism industry. Thus, the education system in hospitality and tourism need some considerations to prepare the students attitude that will develop their self image so the students will firmed that they could enter the tourism industry. The students perceived good image of tourism career, however they also aware that the community has not have the same image or perception with them. This research only focus on the behavioral intention on the students' job choice, so further research should be conducted to understand students commitment to work at tourism industry after they graduate from their study.

\section{ACKNOWLEDGMENT}

This research was sponsored by Universitas Pendidikan Indonesia under Competency Affirmation Research Grant Scheme.

\section{REFERENCES}

[1] D. Jackson, "Career Choice Status Among Undergraduates and The Influence of Work-Integrated Learning". Sagepub. Australian Journal of Career Deveopment, Vol. 24 (I), 3-14

[2] T. Agarwala. Factors influencing career choice of management students in India. Career Development International, 2008. 13(4): 362-376.

[3] I. Gati, L. Asulin-Peretz, A. Fisher, A. Emotional and personality-related career decision-making difficul- ties a 3-year follow-up. The Counseling Psychologist, 2012 40(1): 6-27.

[4] T. Zellweger, P. Sieger, \& F. Halter. Should I stay or should I go? Career choice intentions of students with family business background. Journal of Business Venturing, 2011. 26(5): 521-536.

[5] R. Reese \& C. Miller, C.. Effects of a university career development course on career decision-making self-efficacy. Journal of Career Assessment, 2011. 14(2): 252-266.

[6] Z. King. Career self-management: Its nature, causes and consequences. Journal of Vocational Behavior, 2004. 65(1): 112-133.

[7] K. Robertson, S. Smeets, D. Lubinski, \& C. Benbow. Beyond the threshold hypothesis even among the gifted and top math/science graduate students, cog- nitive abilities, vocational interests, and lifestyle prefer- ences matter for career choice, performance, and persistence. Current Directions in Psychological Science, 2010.19(6): 346-351.

[8] R. Jain \& S. Jain, S. Conceptualization, measure development and empirical assessment of career oriented attitudes and employability of technology graduates. Vision: The Journal of Business Perspective, 2013. 17(2): 143-157

[9] P. Mcllveen, L. Burton, \& G. Beccaria. A short form of the career futures inventory. Journal of Career Assessment, 2013, 21(1): 127-138.

[10] P.Petrova and D. Ujma. Students' Awareness of the importance of transferable skills for employability. Hospitality, Leisure, Sport, and Tourism Network. 2006. p 1-9

[11] K. Walsh, S. Chang, E.Y.C Tse. Understanding Students' Intentions to join the hospitaloty industry: The role of Emotional Intelligence, Service Orientation, and Industry Satisfaction. Cornell Hospitality Quarterly 2015, Vol. 56(4) 369-382

[12] Kelley-Patterson, D., and C. George. 2001. Securing graduate commitment: An exploration of the comparative expecta- tions of placement students, graduate recruits and human resource managers within the hospitality, leisure and tourism industries. International Journal of Hospitality Management 20:311-23

[13] O'Leary, S., and J. Deegan. 2005. Career progression of Irish tourism and hospitality management graduates. International Journal of Contemporary Hospitality Management 17: 421-32.

[14] Richardson, S. 2008. Undergraduate tourism and hospitality student attitudes toward a career in the industry: A preliminary investi- gation. Journal of Teaching in Travel \& Tourism 8:23-46.

[15] Chuang, N.-K., and M. Dellmann-Jenkins. 2010. Career decision making and intention: A study of hospitality undergraduate students. Journal of Hospitality \& Tourism Research 34: 512-30.

[16] Teng, C.-C. 2008. The effects of personality traits and attitudes on student uptake in hospitality employment. International Journal of Hospitality Management 27:76-86.

[17] A. J. Marchante, B. Ortega, R. Pagan. An Analysis of Educational Mismatch and Labor Mobility in The Hospitality Industry. Journal of Hospitality \& Tourism Research, Vol. 31, No. 3, August 2007, 299-320 
[18] A. Ladkin. Hotel general managers: A review of prominent research themes. International Journal of Tourism Research, 1999. 1(3), 167-193.

[19] J.F. Jensen. Improving training in order to upgrade skills in the tourism industry (Final report of Working Group B Tourism and Employment, European Commission). 2001. Retrieved December 2015, from http://europa.eu.int/comm/enterprise/services/tourism/ tourismpublications/documents/la_annex5.pdf

[20] P.M. Burns. Sustaining tourism employment. Journal of Sustainable Tourism, 1993. 1(2), 81-96.
[21] E. Szivas, M. Riley, \& D. Airey. Labor mobility into tourism. Annals of Tourism Research, 2003. 30(1), 63-76.

[22] A. Uygur \& G. Killie. A study into organizational commitment and job involvement: an application towards the personnel in the central organization for ministry of health Turkey. Ozea Journal of Applied Sciences. 2009. 2 (I), 113-125 